\title{
A Study on Relationship between $\mathrm{CO}_{2}$ Emissions and Economic Development in China Based on Dematerialization Theory
}

\author{
Xingjun $\mathrm{Ru}^{1}$, Shaofeng $\mathrm{Chen}^{2}$ \& Hongxiang Dong ${ }^{1}$ \\ ${ }^{1}$ Department of Management, University of Science and Technology of China, Hefei, Anhui, China \\ ${ }^{2}$ Institute of Policy and Management, Chinese Academy of Science, Beijing, China \\ Correspondence: Xingjun Ru, University of Science and Technology of China, Hefei, Anhui, China. E-mail: \\ rxj1986@mail.ustc.edu.cn
}

Received: April 20, 2012 Accepted: May 2, 2012 Online Published: August 15, 2012

doi:10.5539/eer.v2n2p37 URL: http://dx.doi.org/10.5539/eer.v2n2p37

\begin{abstract}
Understanding the relationship between economic development and the factors causing the environmental pressures is the basic premise of formulating and adjusting the environmental policy. A sound environmental policy should be effective to reduce or mitigate the environment pressures and simultaneously maintain economic development. According to the theory of dematerialization, which is a method to describe the relationship between economic growth and the environment pressures, we divide target research stage (1960-2008) into 5 sub-time periods, that is 1960-1969, 1970-1979, 1980-1989, 1990-1999, 2000-2008, then inspect the relationship among GDP per capita, carbon emissions and intensity of carbon emissions in China. We find that absolute dematerialization occurs in 1960-1969, materialization occurs in 1970-1979, relative dematerialization occurs in 1980-1989, 1990-1999 and 2000-2008. On terms of the whole study period, relative dematerialization is occurring; from 1960 to 2008, when economic development changes $1 \%$, carbon emissions, carbon emissions intensity and environmental pressures change $0.59 \%,-0.34 \%$ and $0.84 \%$ respectively, which shows that the relationship of environmental pressures and economic development, carbon emissions and economic development are relative decoupling.
\end{abstract}

Keywords: dematerialization, carbon dioxide emissions, economic development, carbon dioxide emissions intensity, environmental pressures

\section{Introduction}

Climate change issue is a hot topic in current international political, economic and environmental field, which will play an important role in the sustained economic development in all the countries of the world. The key problem of dealing with climate change is reducing greenhouse gas emissions, in which carbon dioxide emission reduction is one of the most important issues. Successful actions on solving climate change problems should meet at least two requirements: On the one hand curb the increase of global carbon emissions effectively; on the other hand, the actions of solving global warming problem should not at the expense of declining economic development and people's living standards (McKinsey Global Institute, 2008). Many scholars carried out theoretical and empirical researches on relationship between carbon dioxide emissions and economic development from the view of EKC hypothesis and decoupling theory. This article will focuse on relationship between Chinese carbon dioxide emission and economic development during the period of 1960-2008, meanwhile applying dematerialization theory to analyze changes of Chinese environmental pressures in the process of economic development.

The research on dematerialization has a rich history. Many scholars defined dematerialization from different perceptions. Herman et al. thought that dematerialization means the decline over time in the weight of the materials used in industrial products, and the change in the amount of waste generated per unit of industrial products (Herman, Arkekani, \& Ausubel, 1989); Labys and Waddell considered dematerialization as "Instead of a once and for all structural change" (Labys \& Waddell, 1989); Bernardini and Galli noted that dematerialization is the reduction of raw material (energy and material) intensity of economic activities, as measured as the ratio of material (or energy) consumption in physical terms to gross domestic product (GDP) in deflated constant terms (Bernardini \& Galli, 1993); Wernick et al. pointed out that dematerialization refers to the absolute or relative reduction in the quantity of materials required to serve economic functions (Wernick, Herman, Govind, \& 
Ausubel, 1996). Based on above definition of dematerialization, Cutler and Matthias defined dematerialization as follow: dematerialization refers to the absolute or relative reduction in the quantity of materials used or the quantity of waste generated in the production of an unit of economic output (Cutler \& Matthias, 1999).

Some researches specially focused on dematerialization from the perspective of the consumption of materials (raw materials). There are six major cases to prove it : Brooks and Andrews studied on intensity of use (IU, that is material use of a unit of economic output) of copper and aluminum from 1926 to 1971 in United States and Canada, they found that IU of copper showed inverted U shape over time, IU for aluminum showed rising trend but declining at end of period (Brooks \& Andrews, 1974); Radcliffe analyzed the IU of American Wood products in 1900-1972, found that IU declines for total products and lumber but IU rises for pulpwood and veneer (Radcliffe, 1976); Malebaum (1978) focus on 12 nonfuel minerals in 10 global regions from 1955 to 1975, and found that inverted U-shaped path for IU as function of GDP for 10 of 12 materials, nonfuel minerals consumption showed a trend of dematerialization (Malebaum, 1978); Larson et al. studied on American material consumption situation by putting emphasis on three traditional materials (steel, cement, paper) and four modern materials (aluminum, chlorine, ammonia, ethylene), they found that IU of both traditional materials and modern materials are decreasing over time, so Larson et al. claimed that U.S. had already achieve the target of dematerialization (Larson, Ross, \& Williams, 1986); Xinwei Zhang et al. analyzed dematerialization of China energy consumption based on the complete decomposition model (Xinwei Zhang, Qiaosheng Wu, \& Jinhua Cheng, 2007); Chen Pan and Zeqiang Fu (2008) studied the impact of material use efficiency, material recycling and product durability on economic activity by establishing a produce process model ,then made an empirical analysis on dematerialization situation of a Chinese Iron and steel enterprise---Baosteel (Chen Pan \& Zeqiang Fu, 2008).

Inverted U-shaped relationship between environmental pressures and economic growth is proved by a number of empirical researches (Magnus, 2002; Markus, 2002; Fatma \& Osman, 2001; Roldan \& Joan, 2001; Matthew, 2004; Richmond \& Kaufmann, 2006; Huang W. M., Lee G. W. M. \& Wu C. C., 2008; Xingjun Ru, Shaofeng Chen, YangLiu \& Liyang Su, 2012), but there are also some evidences indicate that the relationship between environmental pressures and economic growth are Synchronization (Jordi, Emilio, Mario, \& Vittorio, 2002; Alberto \& Marta, 2002), U-shaped relationship (Ariaster \& John, 2005), N-shaped relationship (Birgit \& Michael, 2003; Fatma \& Osman, 2000; Inmaculada, 2004). Xingjun Ru et al. claimed that different options of research samples, time periods, models, and indicators, lack of long time series' data, different countries' natural features, history, culture, socio-economic and technological conditions are all the possible reasons which cause different observations in EKC (inverted U-shaped relationship) hypothesis, however, there is no doubt that inverted U-shaped curve could be one of the effective tools to describe non-synchronous change relationship between environmental pressures and economic growth (Xingjun Ru et al., 2012).

From the above review, we can find that most of the research on material consumption are concentrated in the field of production and consumption and only limited to a single substance or some specific industrial sectors (the most common example is the metal industry), there are little study on the perspective of waste filed. Undoubtedly, study the relationship between economic development and environmental pressure from the view of waste is of great importance. This article will analyze the relationship among Chinese carbon emissions and its impact factors (economic development, population, technology), which is based on Daly's dematerialization analysis model.

\section{Methodologies}

\subsection{Dematerialization Theory}

Herman Daly (1991) defines the concept of dematerialization in the process of explaining environmental pressures from the perspective of environmental macroeconomics. He explains that $S_{t}, P_{t}$ and $U_{t}$ represent economic development scale adapting to the environment, population, environmental demands per capita in year $t$ respectively. Economic development scale is the product of population and environmental demands per capita, so Equation (1) can be obtained:

$$
\mathrm{S}_{\mathrm{t}}=\mathrm{P}_{\mathrm{t}} \times \mathrm{U}_{\mathrm{t}}
$$

In Equation 1, $\mathrm{S}_{\mathrm{t}}$ means material-energy throughput between natural system and economic system, it is composed of $\mathrm{M}_{\mathrm{t}}$ which means material input from natural system to economic system and $\mathrm{W}_{\mathrm{t}}$ which represents material output from economic system back to natural system, so Equation (1) can be showed as follow:

$$
S_{t}=P_{t}\left(\mathrm{M}_{\mathrm{t}}, \mathrm{W}_{\mathrm{t}}\right) \times \mathrm{U}_{\mathrm{t}}\left(\mathrm{M}_{\mathrm{t}}, \mathrm{W}_{\mathrm{t}}\right)
$$


In Equation 2, $\mathrm{U}_{\mathrm{t}}\left(\mathrm{M}_{\mathrm{t}}, \mathrm{W}_{\mathrm{t}}\right)$ is a function of material demanded per capita and pollution per capita, which can be decomposed into two elements: income per capita (that is $\mathrm{y}_{t}$ ) and environmental pressure produced by an unit income $\left(E_{t}\right)$, so Equation 2 can be presented as the following form:

$$
S_{t}=P_{t}\left(\mathrm{M}_{\mathrm{t}}, \mathrm{W}_{\mathrm{t}}\right) \times \mathrm{E}_{\mathrm{t}}\left(\mathrm{M}_{\mathrm{t}}, \mathrm{W}_{\mathrm{t}}\right) \times \mathrm{y}_{\mathrm{t}}
$$

Where $\mathrm{Y}_{\mathrm{t}}$ represents the total income, $\mathrm{M}_{\mathrm{t}} / \mathrm{Y}_{\mathrm{t}}$ and $\mathrm{W}_{\mathrm{t}} / \mathrm{Y}_{\mathrm{t}}$ represent material use and material output (environmental pollution) of an unit of income, we also call them intensity of material use (IU) and intensity of environmental pollution respectively. Both material use and environmental pollution can reflect the material use situations in human economic activities. The reduction of material use intensity (IU) and waste output intensity will cause environmental pressure decrease. Both material use intensity (IU) and material output intensity reducing over time will be regarded as dematerialization in this article. Under the premise of no affecting the results of analysis, we assume that $M_{t}$ is a standard input, and standard value of $M_{t}$ is 1 , so this article just consider environmental pressures from the perspective of pollutant emissions in following description. Equation 3 can also be changed into the following form:

$$
S_{t}=P_{t} \times \mathrm{y}_{\mathrm{t}} \times \frac{\mathrm{W}_{\mathrm{t}}}{\mathrm{Y}_{\mathrm{t}}}
$$

Equation 4 means environmental pressures in year $t$, which is the combined result of population $\left(\mathrm{P}_{t}\right)$, economic development level $\left(\mathrm{y}_{\mathrm{t}}\right)$ and pollution intensity $\left(\mathrm{W}_{\mathrm{t}} / \mathrm{Y}_{\mathrm{t}}\right)$. By taking logarithm and derivative by time on both sides of Equation 4, in which pollution intensity $\left(\mathrm{W}_{\mathrm{t}} / \mathrm{Y}_{\mathrm{t}}\right)$ is represented by $\mathrm{C}_{\mathrm{t}}$, equation $(5)$ can be obtained:

$$
\overline{\mathrm{S}}_{\mathrm{t}}=\mathrm{y}_{\mathrm{t}} \times \mathrm{C}_{\mathrm{t}} \times \overline{\mathrm{P}}_{\mathrm{t}}+\mathrm{P}_{\mathrm{t}} \times \mathrm{C}_{\mathrm{t}} \times \overline{\mathrm{y}_{\mathrm{t}}}+P_{\mathrm{t}} \times \mathrm{y}_{\mathrm{t}} \times \overline{\mathrm{C}}_{\mathrm{t}}
$$

Daly pointed out that relative dematerialization happened when the situation of $\overline{\mathrm{C}}_{t}<0, \overline{\mathrm{y}}_{\mathrm{t}} \geq 0$ and $\overline{\mathrm{S}}_{\mathrm{t}}>0$ occurs, intensity of material use (IU) is decreasing while total material use and economic growth are not reducing; absolute dematerialization happened when the situation of $\overline{\mathrm{S}}_{\mathrm{t}}<0, \overline{\mathrm{y}_{\mathrm{t}}} \geq 0$ and $\overline{\mathrm{C}}_{\mathrm{t}}<0$ occurs, which means total material use and intensity of material use are reducing over time while economic growth is not reducing (Daly, 1991).

Based on above descriptions on dematerialization theory, figure1 shows different degrees of dematerialization in different stages. In Figure 1, environmental pressures can be represented by material use (or the pollutant emissions) and intensity of material use (or pollutant emission intensity), IU represents intensity of material use (or pollutant emissions intensity), Mat represents material use (or the pollutant emissions).

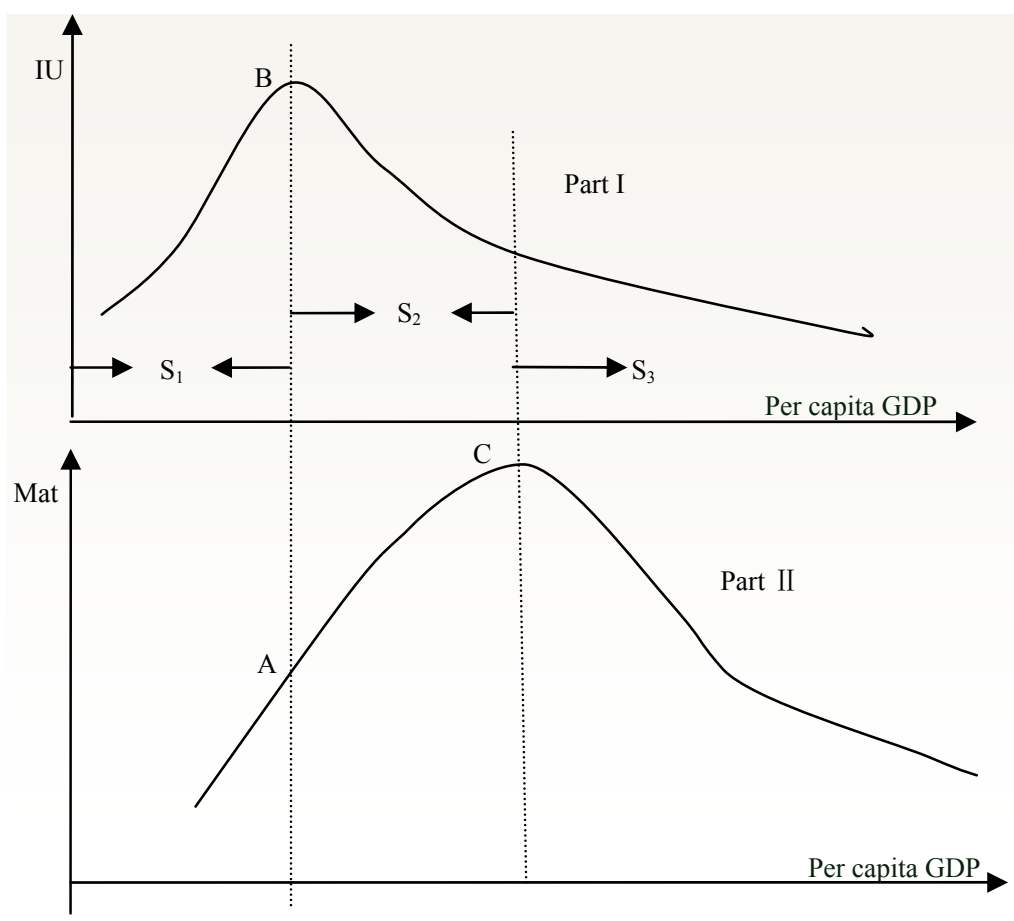

Figure 1. Different dematerialization degrees in different stages 
Figure 1 can be divided into part I (the upper part of Figure 1) and part II (the lower part of Figure 1), part I shows the relationship between use intensity of material (or pollutant emissions intensity) and GDP per capita, part II shows the relationship between material use (or the pollutant emissions) and GDP per capita. Stage $\mathrm{S}_{1}$ is materialization stage, in which economic growth and material use growth is synchronized (It also can be said that economic growth and material use growth is coupling ); stage $\mathrm{S}_{2}$ is relative dematerialization stage, in which economic growth and material use growth toward the same direction, but growth rates of them are different---growth rate of material use is slower than growth rate of economic growth, it can also be said that economic growth and material use growth are relative decoupling; stage $S_{3}$ is an absolute dematerialization stage, in which economic growth continues to increase while the amount of material use is reducing, economic growth and material use are absolute decoupling in this stage.

\subsection{Income Elasticity}

For a further explanation to conclusions of the empirical study, we make an appropriate extension of the above dematerialization theoretical framework. We will introduce the concept of income elasticity in next content. $e_{i}$ represents income elasticity of material use (or the pollutant emissions) which means the changes in the ratio of material use (or the pollutant emissions) when economic development changes $1 \%$.

From equation (4), material use (or the pollutant emissions) per capita can be represented by $y_{t} \times C_{t}, \widehat{y}_{t}+\widehat{C}_{t}$ is the average change rate of material use (or the pollutant emissions) per capita, so income elasticity of material use (or the pollutant emissions) is:

$$
\mathrm{e}_{\mathrm{i}}=\frac{\widehat{\mathrm{y}_{\mathrm{t}}}+\widehat{\mathrm{C}_{\mathrm{t}}}}{\widehat{\mathrm{y}_{\mathrm{t}}}}
$$

Income elasticity of materials use intensity (or pollutant emission intensity) is:

$$
\mathrm{e}_{\mathrm{c}}=\mathrm{e}_{\mathrm{i}}-1
$$

\subsection{Indicators and Data}

Based on Daly's dematerialization theory model described above, we made an empirical analysis by applying Chinese historical data of carbon dioxide emissions, population, GDP from 1960 to2008. In this empirical analysis, indicator of carbon dioxide emissions represent environmental pressures, indicator of GDP per capita represent economic development. Data of population, GDP and carbon dioxide emissions are obtained from World Bank database (World Bank, 2012). In order to eliminate the interference from commodity prices factor, measurement unit of GDP in this article will adopt constant 2000 US\$.

\section{An Empirical Analysis in China Based on Dematerialization Theory}

3.1 1960-2008 Relationship of Economic Development, Carbon Dioxide Emissions and Carbon Dioxide Emissions Intensity in China

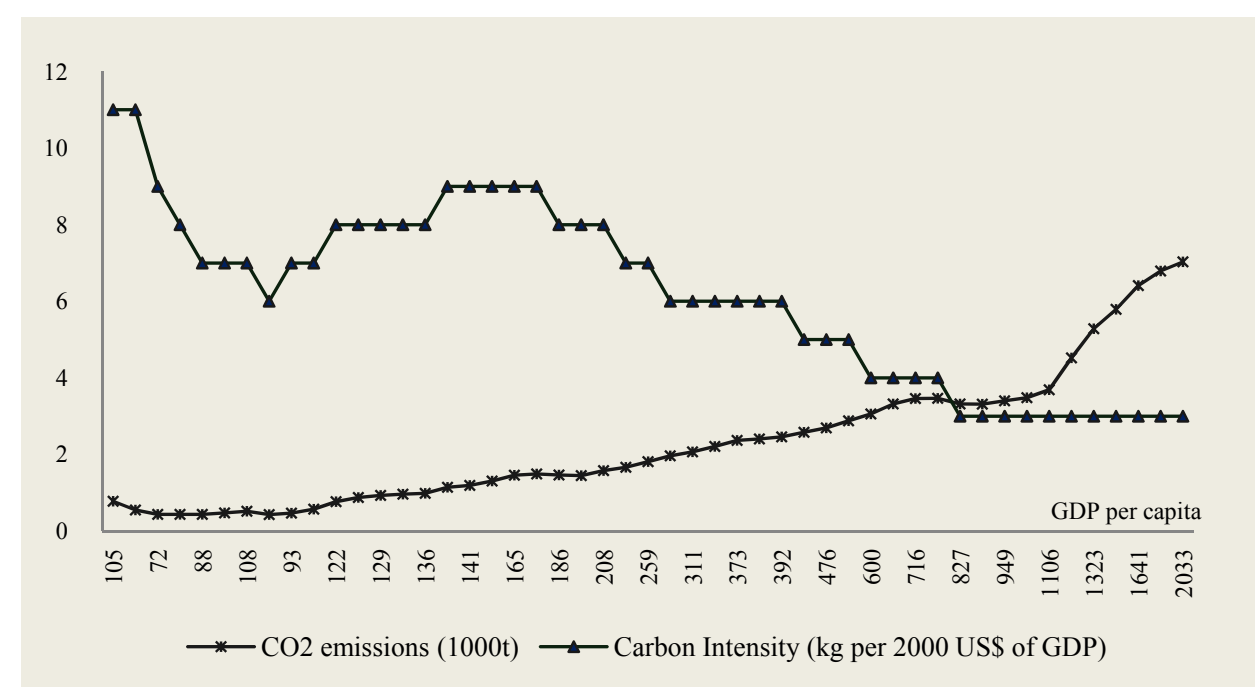

Figure 2. 1960-2008 relationship among GDP per capita, carbon emissions and intensity of carbon emissions in China 
Figure 2 shows relationship among GDP per capita, carbon emissions and intensity of carbon emissions in China from 1960-2008. Chinese GDP per capita continued to increase accompanied with carbon emissions increasing, and environmental pressures increasing. Intensity of carbon emissions fluctuating with GDP per capita continued to rise, but the overall trend of carbon emissions' intensity is declining. Carbon emissions' intensity fluctuations mainly occurred in the period of 1960-1978, it is decreasing year by year after 1978. This situation due to implementation of the policy of reform and opening up started from 1978 in China. According to Daly's dematerialization theory, we think that China is in the stage of relative dematerialization.

\subsection{Analysis of Carbon Dioxide Emissions in China Based on Dematerialization Theory}

Impact factors of environmental pressures are composed of economic development, population and technological progress. Average change rate of environmental pressures (carbon emissions), economic development (GDP per capita), population and technological progress (represented by intensity of carbon emissions) are represented by $\widehat{S}_{t}, \hat{y}_{t}, \widehat{P}_{t}, \widehat{C}_{t}$ respectively, from Equation 5 mentioned above, interference terms are ignored, we can obtain Equation 8:

$$
\widehat{\mathrm{S}}_{\mathrm{t}}=\hat{\mathrm{y}}_{\mathrm{t}}+\widehat{\mathrm{P}}_{\mathrm{t}}+\widehat{\mathrm{C}}_{\mathrm{t}}
$$

We will divide the target research period (1960-2008) into 5 sub-time periods, that is 1960-1969, 1970-1979, 1980-1989, 1990-1999, 2000-2008. $\widehat{\mathrm{S}}_{\mathrm{t}}, \widehat{\mathrm{y}}_{\mathrm{t}}, \widehat{\mathrm{P}}_{\mathrm{t}}, \widehat{\mathrm{C}}_{\mathrm{t}}$ of 5 sub-time periods are showed in Table 1.

Table 1. The average change rate of by $\widehat{\mathrm{S}}_{t}, \widehat{\mathrm{y}}_{\mathrm{t}}, \widehat{\mathrm{P}}_{\mathrm{t}}, \widehat{\mathrm{C}}_{\mathrm{t}}$ in China from 1960 to 2008

\begin{tabular}{ccccc}
\hline Year & $\widehat{\mathrm{S}}_{\mathrm{t}}(\%)$ & $\widehat{\mathrm{P}}_{\mathrm{t}}(\%)$ & $\widehat{\mathrm{y}}_{\mathrm{t}}(\%)$ & $\widehat{\mathrm{C}}_{\mathrm{t}}(\%)$ \\
\hline $1960-1969$ & -3.30 & 1.98 & 0.00 & -4.90 \\
$1970-1979$ & 7.62 & 2.41 & 4.09 & 1.32 \\
$1980-1989$ & 5.66 & 1.47 & 8.36 & -3.15 \\
$1990-1999$ & 3.38 & 1.10 & 9.44 & -7.41 \\
$2000-2008$ & 8.39 & 0.53 & 8.83 & 0.00 \\
$1960-2008$ & 4.69 & 1.44 & 6.37 & -2.67 \\
\hline
\end{tabular}

It can be drawn from the table 1 that China population growth declining in general: population increased from 1960 to1979, after that population average change rate showed a continued downward trend, average change rate of population decreased by $0.53 \%$ during the last sub-time period; average change rate of economic development (GDP per capita) showed an upward trend on the whole, average change rate of economic development is $6.37 \%$ from 1960 to 2008, and it is above 8\% during the period of 1980-2008; average change rate of carbon emissions intensity showed an downward trend on the whole, it is decreasing by $2.67 \%$ from 1960 to 2008 , there is a significant drop occurred during the $4^{\text {th }}$ sub-time period $(1990-1999)$ which is decreased by $7.41 \%$, carbon emissions intensity average change rate is below 0 during the $1^{\text {st }}(1960-1969), 3^{\text {rd }}(1980-1989), 4^{\text {th }}(1990-1999)$ sub-time period.

Carbon emissions change is the result of joint actions of population, economic development and carbon emission intensity. China social depression occurs in 1960-1969, which leading to economic stagnation and carbon emissions reduction, after that average change rate of carbon emissions increased from 1970 to 2008. According to Daly's dematerialization theory model and average change rate of environmental pressures (carbon emissions), economic development (GDP per capita), population and technological progress (carbon emissions intensity ) in China from 1960-2008 showed in Table1, we can find that:

- In 1960-1969, economic development does not change while carbon emissions and carbon emissions intensity are decline, absolute decoupling between economic development and carbon emissions is occurred in this period, so this period is an absolute dematerialization.

- In 1970-1979, economic development, carbon emissions and carbon emissions intensity are increasing, so materialization occurs in this period.

- In 1980-1989, both economic development and carbon emissions are rising while carbon emissions intensity is decreasing, growth rate of carbon emissions is lower than that of economic development, so this period is a relative dematerialization. 
- In 1990-1999, carbon emissions intensity is decreasing while both economic development and carbon emissions are rising, but growth rate of carbon emissions is lower than that of economic development, relative dematerialization occurs in this period.

- $\quad$ In 2000-2008, carbon emissions intensity growth does not change while economic development and carbon emissions are increasing, but growth rate of carbon emissions is slightly lower than that of economic development, so relative dematerialization occurs in this period.

- In 1960-2008, economic development and carbon emissions are increasing but economic growth is higher than carbon emissions growth, meanwhile, carbon emissions intensity growth is decreasing, on the terms of the whole study period, relative dematerialization is occurring .

\subsection{Analysis of Income Elasticity of Environmental Pressures}

Income elasticity of carbon emissions refers to the changes in the ratio of carbon emissions when economic development changes $1 \%$. Average change rate of economic development is $6.37 \%$ from 1960 to 2008 in China, average change rate of carbon emissions is $4.69 \%$, so we can get income elasticity of carbon emissions $\left(\mathrm{e}_{\mathrm{i}}=0.59\right)$ and income elasticity of carbon emissions' intensity $\left(\mathrm{e}_{\mathrm{c}}=-0.34\right)$ according to Equation 6 and Equation 7. Assumed that income elasticity of population is $e_{p}$, we can get income elasticity of environmental pressures (namely $\mathrm{m}$ ) from Equation 8, that is $m=e_{c}+1+e_{p}$, income elasticity of environmental pressures is 0.84 , which means that environmental pressures changes $0.84 \%$ when economic development changes $1 \%$.

\section{Conclusion and Discussion}

\subsection{Conclusion}

It is a very important issue for China to find a solution on how to achieve absolute dematerialization, which means China should strive to decrease carbon emissions, meanwhile, does not affect economic development speed. Based on Daly's dematerialization theory and income elasticity theory, we analyzed relationship between China economic development and environmental pressures which are presented by carbon emissions from 1960 to 2008, conclusions can be drawn as following:

- On the terms of 5 sub-time periods, absolute dematerialization occurred in 1960-1969, materialization occurred in 1970-1979, relative dematerialization occurred in 1980-1989, 1990-1999 and 2000-2008.

- $\quad$ On the terms of the whole period, relative dematerialization is occurred in 1960-2008.

- From 1960 to 2008 , income elasticity of carbon emissions is 0.59 and income elasticity of carbon emissions' intensity is -0.34 , income elasticity of environmental pressures is 0.84 , which means that when economic growth changes $1 \%$, carbon emissions, carbon emissions' intensity and environmental pressures changes $0.59 \%,-0.34 \%$ and $0.84 \%$ respectively, which shows that the relationship of environmental pressures and economic development, carbon emissions and economic development are relative decoupling.

\subsection{Discussion}

Although relative dematerialization occurs in the 3rd, 4th sub-time period, there are differences in dematerialization degree. According to observing the gap between economic growth and carbon emissions growth in 2 sub-time period, we can find that relative dematerialization in 4th sub-time period is stronger than that of 3rd sub-time period.

Pursuit of achieving absolute dematerialization between economic growth and environmental pressures should not at the expense of economic regression or economic stagnation. As a matter of fact, living standards of China residents from 1960-1969 is declining. Based on the above analysis, we think that absolute dematerialization occurs in China from 1960-1969 is a kind of negative absolute dematerialization.

\section{Acknowledgements}

This article is founded by CAS Strategic Priority Research Program-Carbon Budget and Related Issues: Policy Simulation Forum for Dealing with Climate Change and National Development (sub-project 4) (XDA05150401) and the Knowledge Innovation Program of the Chinese Academy of Sciences (Grant No.kzcx2-yw-325).

\section{References}

Alberto, A., \& Marta, E. (2002). Economic growth and greenhouse gas emissions. Ecological Economics, 40(1), 23-37. http://dx.doi.org/10.1016/S0921-8009(01)00272-5

Bernardini, O., \& Galli, R. (1993). Dematerialization: Long-term trends in the intensity of use of materials and energy. Futures, 431-448. http://dx.doi.org/10.1016/0016-3287(93)90005-E 
Birgit, F., \& Michael, G. (2003). Determinants of CO2 emissions in a small open economy. Ecological Economics, 45(1), 133-148. http://dx.doi.org/10.1016/S0921-8009(03)00008-9

Brooks, D. B., \& Andrews, P. W. (1974). Mineral resources, economic growth, and world population. California: Science, 185, 13-20. http://dx.doi.org/10.1126/science.185.4145.13

Chen Pan, \& Zeqiang Fu. (2008). Theoretical Model and Case Study of Dematerialization, Yunnan (China). Ecological Econimy, 12, 54-60.

Chimeli, A. B., \& Braden, J. B. (2005). Total Factor Productivity and the Environmental Kuznets curve. Journal of Environmental Economics and Management, 49(2), 366-380. http://dx.doi.org/10.1016/j.jeem.2004.06.003

Cutler, J. C., \& Matthias, R. (1999). Indicators of Dematerialization and the Materials Intensity of Use, New Haven. Journal of Industrial Ecology, 2(3), 15-36.

Daly, H. (1991). Steady state economics (2nd ed.). Washington: Island press.

Fatma, T., \& Osman, Z. (2000). Searching for a Kuznets curve in environmental efficiency using kernel estimation. Economics Letters , 68(2), 217-223. http://dx.doi.org/10.1016/S0165-1765(00)00250-0

Herman, R., Arkekani, S. A., \& Ausubel, J. H. (1989). Dematerialization. In Technology and environment, Washington, DC: National Academy Press, pp. 50-69.

Huang, W. M., Lee, G. W. M., \& Wu, C. C. (2008). GHG emissions, GDP growth and the Kyoto Protocol: a revisit of environmental Kuznets curve hypothesis. Energy Policy, 36, 239-247. http://dx.doi.org/10.1016/j.enpol.2007.08.035

Inmaculada, A. (2004). Pooled mean group estimation of an environmental Kuznets curve for $\mathrm{CO}_{2}$. Economics Letters, 82(1), 121-126. http://dx.doi.org/10.1016/j.econlet.2003.07.008

Jordi, R., Emilio, P., Mariona, F., \& Vittorio, G. (2001). Economic Growth and Atmospheric Pollution in Spain: discussing the environmental Kuznets curve hypothesis. Ecological Economics, 39(1), 85-99. http://dx.doi.org/10.1016/S0921-8009(01)00195-1

Labys, W. C., \& Waddell, L. M. (1989). Commodity lifecycles in U.S. materials demand. Resources Policy, 15, 238-251. http://dx.doi.org/10.1016/0301-4207(89)90055-X

Larson, E. D., Ross, M. H., \& Williams, R. H. (1986).Beyond the era of materials. Scientific American, 254, 34-41. http://dx.doi.org/10.1038/scientificamerican0686-34

Labson, B. S. \& Crompton, P. L. (1993). Common trends in economic activity and metals demand: Cointegration and the intensity of use debate. Journal of Environmental Economics and Management, 25, 147-161. http://dx.doi.org/10.1006/jeem.1993.1039

Malenbaum, W. (1978). World demand for raw materials in 1985 and 2000. New York: McGraw-Hill.

Matthew, A. C. (2004). Trade, the Pollution Haven Hypothesis and the Environmental Kuznets Curve: $\begin{array}{lllll}\text { Examining the Linkages. Ecological } & \text { Economics, }\end{array}$ http://dx.doi.org/10.1016/j.ecolecon.2003.09.007

Magnus, L. (2002). An EKC pattern in historical perspective: carbon dioxide emissions, technology, fuel prices and growth in Sweden (1870-1997). Ecological Economics, 42(2), 333-347. http://dx.doi.org/10.1016/S0921-8009(02)00108-8

Markus, P. (2002). Technical progress, structural change, and the environmental Kuznets curve. Ecological Economics, 42(2), 381-389.

McKinsey Global Company. (2008). The carbon productivity challenge: Curbing climate change and sustaining economic growth. The McKinsey Quarterly, 7, 2-33.

Radcliffe, S. V. (1976). World changes and chances: Some new perspectives for materials. Science, 191, 700-707. http://dx.doi.org/10.1126/science.191.4228.700

Richmond, A. K., \& Kaufmann, R. K. (2006). Is there a turning point in the relationship between income and energy use and/or carbon emissions? Ecological Economics, 56, 176-189. http://dx.doi.org/10.1016/j.ecolecon.2005.01.011

Roldan, M., Joan, M. A. (2001). Trade and the environment: from a "Southern" perspective. Ecological Economics, 36(2), 281-297. 
Taskin, F., \& Zaim, O. (2001). The role of international trade on environmental efficiency: a DEA approach. Economic Modeling, 18(1), 1-17. http://dx.doi.org/10.1016/S0264-9993(00)00025-0

Wernick, I. K., Herman, R., Govind, S., \& Ausubel, J. H. (1996). Materialization and dematerialization: Measures and trends. Daedalus, 125, 171-198.

World Bank. (2012). Retrieved from http://data.worldbank.org/data-catalog

Xingjun Ru, Shaofeng Chen, YangLiu, \& Liyang Su. (2012). A Study on Evolution and Driving forces of Carbon Dioxide Emissions. Journal of Sustainable Development, 5(5), 111-120. http://dx.doi.org/10.5539/jsd.v5n5p111 